\section{Effect of Low Fluoride Acidic Dentifrices on Dental Remineralization}

Fernanda Lourenção Brighenti' ${ }^{1}$ Eliana Mitsue Takeshita ${ }^{1}$, Camila de Oliveira Sant'ana', Marilia Afonso Rabelo Buzalaf², Alberto Carlos Botazzo Delbem ${ }^{1}$

This study evaluated the capacity of fluoride acidic dentifrices ( $\mathrm{pH} 4.5)$ to promote enamel remineralization using a $\mathrm{pH}$ cycling model, comparing them with a standard dentifrice $(1,100 \mu \mathrm{gF} / \mathrm{g})$. Enamel blocks had their surface polished and surface hardness determined (SH). Next, they were submitted to subsurface enamel demineralization and to postdemineralization surface hardness analysis. The blocks were divided into 6 experimental groups ( $n=10$ ): placebo (without $F, \mathrm{pH} 4.5$, negative control), 275, 412, 550, 1,100 $\mu \mathrm{gF} / \mathrm{g}$ and a standard dentifrice (positive control). The blocks were submitted to $\mathrm{pH}$ cycling for 6 days and treatment with dentifrice slurries twice a day. After $\mathrm{pH}$ cycling, surface and crosssectional hardness were assessed to obtain the percentage of surface hardness recovery $\left(\% \mathrm{SH}_{\mathrm{R}}\right)$ and the integrated loss of subsurface hardness $(\triangle \mathrm{KHN})$. The results showed that $\% \mathrm{SH}_{\mathrm{R}}$ was similar among acidic dentifrices with $412,550,1,100 \mu \mathrm{gF} / \mathrm{g}$ and to the positive control (Tukey's test; $p>0.05$ ). For $\Delta K H N$, the acidic dentifrice with $550 \mu \mathrm{g} \mathrm{F/g} \mathrm{showed} \mathrm{a}$ better performance when compared with the positive control. It can be concluded that acidic dentifrice $550 \mu \mathrm{gF} / \mathrm{g}$ had similar remineralization capacity to that of positive control.

\author{
'Department of Pediatric \\ Dentistry, Araçatuba Dental \\ School, UNESP - Univ Estadual \\ Paulista, Araçatuba, SP, Brazil \\ ${ }^{2}$ Department of Biological Sciences, \\ Bauru Dental School, USP - University \\ of São Paulo, Bauru, SP, Brazil \\ Correspondence: Alberto Carlos \\ Botazzo Delbem, Rua José Bonifácio, \\ 1193, 16015-050 Araçatuba, SP, \\ Brasil. Tel. +55-18-3636-3314. \\ e-mail: adelbem@foa.unesp.br
}

Key Words: dentifrices, dental enamel, fluoride, dental caries, tooth remineralization.

\section{Introduction}

As a result of the widespread availability of various fluoride products, dental caries rates have greatly reduced. However, this wide availability has also promoted an increase in dental fluorosis (1). Fluoride (F) dentifrices contribute to approximately $57 \%$ of the total fluoride ingestion by children aged 4 to 6 years because the swallowing reflex is not totally developed by children at this age (2). Therefore, some authors have emphasized the need for preventive measures to avoid excessive fluoride ingestion from dentifrices such as reducing the amount of fluoride placed on toothbrushes, limiting to twice a day the use of dentifrices during toothbrushing, supervising children during tooth brushing and developing dentifrices with low fluoride concentration (3).

However, fluoride reduction in dentifrices must be followed by the addition of sources capable to maintain a similar effectiveness to that of a standard dentifrice with $1,100 \mu \mathrm{gF} / \mathrm{g}$. It is known that the main product formed after fluoride topical application is calcium fluoride $\left(\mathrm{CaF}_{2}\right)$, which is responsible for fluoride anticariogenic action. $\mathrm{CaF}_{2}$ is a reservoir of fluoride and calcium and both are important ions to promote enamel remineralization (4). The higher $\mathrm{CaF}_{2}$ formation, the greater fluoride availability during cariogenic challenge. Saxegaard and Rølla (5) showed that $\mathrm{CaF}_{2}$ formation on enamel increases in acidic environments. Therefore, the caries prevention ability of low $\mathrm{F}$ dentifrices could be maintained by reducing its $\mathrm{pH}$ from the conventional neutral (7.0) to acidic (5.5 or lower).

Low $\mathrm{F}$ acidic dentifrices have shown to be able to interfere in enamel demineralization $(6,7)$. A dentifrice with $550 \mu \mathrm{gF} / \mathrm{g} \mathrm{pH} 5.5$ showed the same ability in preventing enamel demineralization as a dentifrice with $1,100 \mu \mathrm{gF} / \mathrm{g}$ (6). Alves et al. (8) observed better results in dentifrices with $412 \mu \mathrm{gF} / \mathrm{g} \mathrm{pH}$ 4.5. However, there is no data related to the capacity of these dentifrices to remineralize early caries lesions. A sensible methodology to verify dose response relationship in acidic dentifrices using an in vitro model (9) is required. Thus, the aim of this study was to evaluate the capacity of low fluoride acidic dentifrices (pH 4.5) in promoting enamel remineralization when compared with a standard dentifrice using an in vitro $\mathrm{pH}$ cycling model.

\section{Material and Methods Experimental Design}

Enamel blocks ( $4 \mathrm{~mm} \times 4 \mathrm{~mm}$ ) obtained from bovine incisors had their enamel surfaces polished and surface hardness $(\mathrm{SH})$ determined. After subsurface enamel demineralization, the blocks were submitted to postdemineralization surface hardness $\left(\mathrm{SH}_{1}\right)$ assessment and were randomized in six groups $(n=10)$ according to mean percentage of mineral loss $(-71.2 \%$ to $-96.0 \%)$ and their confidence interval $(\mathrm{p}<0.05)$. Experimental acidic dentifrices were placebo $(0 \mu \mathrm{gF} / \mathrm{g}), 275,412,550$ and $1,100 \mu \mathrm{gF} / \mathrm{g}, \mathrm{pH}$ 4.5. A commercial dentifrice was used as gold standard $\left(\mathrm{Crest}^{\mathrm{TM}}, 1,100 \mu \mathrm{gF} / \mathrm{g}, \mathrm{pH}\right.$ 7.0). The enamel blocks were submitted to $\mathrm{pH}$ cycling for six days. Twice a day, the blocks were treated with dentifrice slurries. After $\mathrm{pH}$ cycling, surface $\left(\mathrm{SH}_{2}\right)$ and cross-sectional hardness were assessed to calculate, respectively, the percentage 
of surface hardness recovery $\left(\% \mathrm{SH}_{\mathrm{R}}\right)$ and integrated loss of subsurface hardness $(\triangle K H N)$.

\section{Toothpaste Formulation and Fluoride, $\mathrm{pH}$ and Phosphorus Assessment}

The experimental dentifrices were manufactured by FGM Produtos Odontológicos Ltda and had the following ingredients: carboxymethylcellulose, sodium methylp-hydroxybenzoate, sodium saccharin, peppermint oil, glycerol, hydrated silica, sodium lauryl sulfate, water and sodium fluoride ( $\mathrm{NaF}$ ). NaF was added to achieve the desired concentration $(275,412,550$ and $1,100 \mu \mathrm{gF} / \mathrm{g})$. The $\mathrm{pH}$ was set to 4.5 using phosphoric acid. A dentifrice without $F$ and pH 4.5 (negative control) and a standard dentifrice (Crest; Procter \& Gamble, Cincinnati, OH, USA, pH 7.0, 1,100 $\mu \mathrm{g}$ $\mathrm{F} / \mathrm{g}$, positive control) were also used.

Fluoride assessment in toothpastes was done according to Brighenti et al. (6). After water dispersion, a sample from the suspension was treated with $2 \mathrm{M} . \mathrm{L}^{-1} \mathrm{HCl}$ for total $F$ assessment. For ionic $F$ assessment, supernatants were obtained by centrifuge $(906 \times g ; 20 \mathrm{~min})$. The same volume of TISAB II ("Total ionic strength adjustment buffer"; Orion Research Inc., Beverly, MA, USA) was added to the to the colorimetric determination as described by Fiske and Subbarow (10) in the supernatants obtained after centrifuge (906×g; $20 \mathrm{~min})$.

The $\mathrm{pH}$ in dentifrices slurries $(1: 3 \mathrm{w} / \mathrm{w})$ was determined using a pH electrode (2A09E; Analyser, São Paulo, SP, Brazil) calibrated with $\mathrm{pH} 7.0$ and 4.0 standards.

\section{Subsurface Enamel Demineralization}

Before induction of subsurface enamel demineralization, enamel blocks were selected by surface hardness (SH) utilizing a microhardness tester (HMV-2000; Shimadzu Corp., Kyoto, Japan) attached to CAMS-WIN Software (NewAge Industries, Southampton, PA, USA) to analyze the images. Five indentations spaced $100 \mu \mathrm{m}$ from each other were made at the center of the enamel surface (SH) $(25 \mathrm{~g}, 10 \mathrm{~s})$. Blocks with hardness values between 336.0 to $391.6 \mathrm{kgf} / \mathrm{mm}^{2}$ were selected. Subsurface enamel demineralization was carried out using a modified model according to Queiroz et al. (11). The blocks were immersed individually in $32 \mathrm{~mL}$ of a solution containing $1.3 \mathrm{mM} \cdot \mathrm{L}^{-1}$ calcium, $0.78 \mathrm{mM} . \mathrm{L}^{-1}$ phosphate in $0.05 \mathrm{mM}^{-L^{-1}}$ acetate buffer, pH 5.0; $0.03 \mu \mathrm{g} / \mathrm{mL} \mathrm{F;} \mathrm{for} 16 \mathrm{~h}$ at $37^{\circ} \mathrm{C}$ (12). After that, post-demineralization surface hardness $\left(\mathrm{SH}_{1}\right)$ was measured with the same parameters described previously.
Indentations for $\mathrm{SH}_{1}$ were made $100 \mu \mathrm{m}$ from each other and from the baseline indentations (SH). The percentage of surface hardness loss was calculated ([[SH1 - SH]/SH] ${ }^{*} 100$ ) to randomize the enamel blocks in the treatment groups.

\section{pH Cycling and Dentifrice Treatments}

To evaluate the effect of dentifrice treatment on enamel remineralization, a pH cycling model based on Vieira et al. (9) was used. During six days the blocks were submitted to $\mathrm{pH}$ cycling at $37^{\circ} \mathrm{C}$. The blocks were immersed individually in a remineralization solution $\left(1.5 \mathrm{mM} . \mathrm{L}^{-1}\right.$ calcium, 0.9 $\mathrm{mM} . \mathrm{L}^{-1}$ phosphate, $150 \mathrm{mM} . \mathrm{L}^{-1}$ potassium chloride in

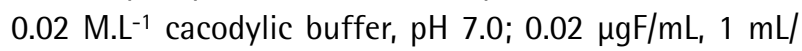
$\mathrm{mm}^{2}$ ) for $22 \mathrm{~h}$. The cariogenic challenge was promoted by a demineralization solution $\left(2.0 \mathrm{mM} . \mathrm{L}^{-1}\right.$ calcium and phosphate in $75 \mathrm{mM} \mathrm{LL}^{-1}$ acetate buffer, $\mathrm{pH} 4.7 ; 0.03 \mu \mathrm{gF} / \mathrm{mL}$, $3 \mathrm{~mL} / \mathrm{mm}^{2}$ ) for $2 \mathrm{~h}$ perday. The solution was refreshed daily. Twice a day, enamel blocks were treated with toothpaste/ deionized water slurries (1:3 w/w, $2 \mathrm{~mL} / \mathrm{block})$ under agitation (1 $\mathrm{min}$ ). Deionized water rinses were performed between each step.

\section{Hardness Analysis}

After $\mathrm{pH}$ cycling, enamel surface hardness $\left(\mathrm{SH}_{2}\right)$ was determined using the same parameters above. Five indentations spaced $100 \mu \mathrm{m}$ from each other and from the baseline indentations were performed. The percentage of surface hardness recovery $\left(\% \mathrm{SH}_{\mathrm{R}}=\left(\left(\mathrm{SH}_{2}-\mathrm{SH}_{1}\right) /\left(\mathrm{SH}-\mathrm{SH}_{1}\right)\right)\right.$ $\mathrm{x} 100)$ was calculated (9).

Next, the enamel blocks were longitudinally sectioned through their center and embedded in acrylic resin with the cut face exposed and gradually polished. For the cross-sectional hardness measurements, three rows of nine indentations spaced $100 \mu \mathrm{m}$ from each other were made at different distances from the outer enamel surface $(10,30$, $50,70,90,110,130,220$ and $330 \mu \mathrm{m})$, under a $25 \mathrm{~g}$ load for $10 \mathrm{~s}$. The mean value of each distance was calculated. Integrated hardness (KHN x $\mu \mathrm{m})$ of the lesion into sound enamel was calculated by the trapezoidal rule (GraphPad Prism, version 3.02; GraphPad Software Inc., La Jolla, CA, USA) and subtracted from the integrated hardness of sound enamel to obtain the integrated loss of subsurface hardness ( $\triangle K H N)$ (13).

\section{Statistical Analysis}

The analysis was performed by GraphPad Prism (version 3.02) software (GraphPad Software, Inc., SAn Diego, CA, USA), with a significance level of $5 \% . \mathrm{SH}_{1} \mathrm{SH}_{1}, \mathrm{SH}_{2}, \% \mathrm{SH}_{\mathrm{R}}$ and $\triangle K H N$ were submitted to normality (Kolmogorov-Smirnov's) and homogeneity (Bartlett's) tests. The values for $\mathrm{SH}_{1} \mathrm{SH}_{1}$, $\mathrm{SH}_{2}$ and $\% \mathrm{SH}_{\mathrm{R}}$ were normal and homogeneous and were thus submitted to one-way analysis of variance and Tukey's 
test. The values for $\triangle \mathrm{KHN}$ were heterogeneous and were submitted to Kruskal-Wallis test followed by Dunn test. The hardness values in function of depth were submitted to two-way analysis of variance and Student-Newman-Keuls's test. Pearson's correlation coefficients were calculated considering fluoride and phosphorus concentration in dentifrice and also $\% \mathrm{SH}$ and $\triangle \mathrm{KHN}$.

\section{Results}

The mean (SD) $\mathrm{pH}$ of dentifrice slurries during the treatments were $4.32(0.27)$ for the acidified dentifrices and $7.56(0.22)$ for the positive control group. Total and ionic fluoride and phosphorus in experimental dentifrices and positive control are represented in Figure 1. All dentifrices showed expected values for fluoride concentration. The acidified dentifrice with $1,100 \mu \mathrm{gF} / \mathrm{g}$ and positive control showed higher phosphorus concentration in comparison to other groups (Fig. 1).

The mean values of initial surface (SH) and post demineralization surface $\left(\mathrm{SH}_{1}\right)$ hardness were similar ( $p>0.05$ ) among groups (Table 1). Hardness after $\mathrm{pH}$ cycling

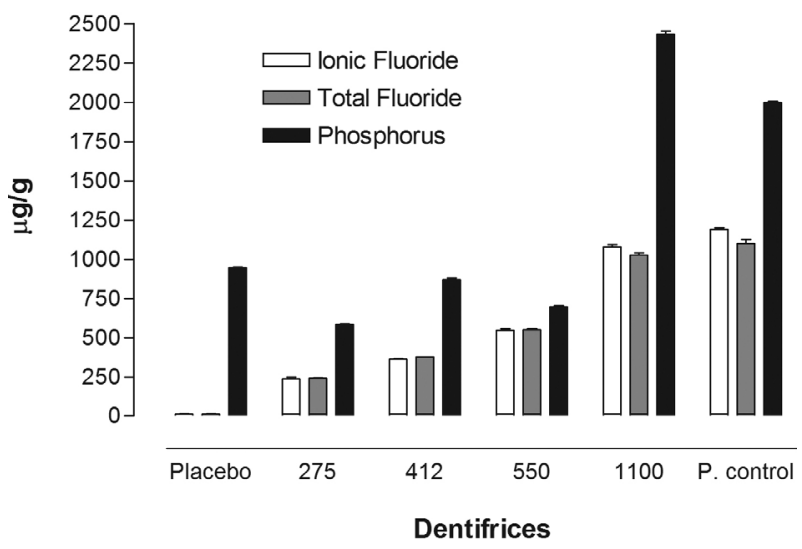

Figure 1. Graphic presentation of mean values of fluoride and phosphorus in the experimental dentifrices and positive control $(n=6)$. The bars denote standard deviations.
$\left(\mathrm{SH}_{2}\right)$, showed no statistically significant difference between groups 275412,550 and 1,100 when compared with positive control ( $p>0.05$ ). Acidic dentifrices with 412, 550 and 1,100 $\mu \mathrm{gF} / \mathrm{g}$ showed similar $\% \mathrm{SH}_{\mathrm{R}}$ to that of positive control ( $p>0.05$ ) (Table 1). A good and positive correlation was observed between fluoride concentration in dentifrice and $\mathrm{SH}_{2}(r=0.81 ; p<0.001)$ and between fluoride concentration in dentifrice and $\% \mathrm{SH}_{R}(r=0.80 ; p<0.001)$. There was a mild positive correlation between $\mathrm{P}$ concentration in dentifrice and $\mathrm{SH}_{2}(r=0.54 ; p<0.001)$, and $\% \mathrm{SH}_{\mathrm{R}}(r=0.56 ; p<0.001)$.

Regarding $\triangle K H N$ (Table 1), acidic dentifrice with 550 $\mu \mathrm{gF} / \mathrm{g}$ showed lower values than positive control $(p<0.05)$, but was similar to 412 and $1,100 \mu \mathrm{gF} / \mathrm{g}(\mathrm{p}>0.05)$ and there were no differences between $412 \mu \mathrm{g} \mathrm{F/g}$ dentifrice and the positive control ( $p>0.05)$. A negative correlation was observed between $\triangle K H N$ and fluoride in dentifrice $(r=-0.67$; $\mathrm{p}<0.001)$ and between $\triangle K H N$ and phosphorus in dentifrice $(r=-0.35 ; p=0.037)$. Figure 2 shows the cross-sectional hardness profiles at different depths in enamel blocks.

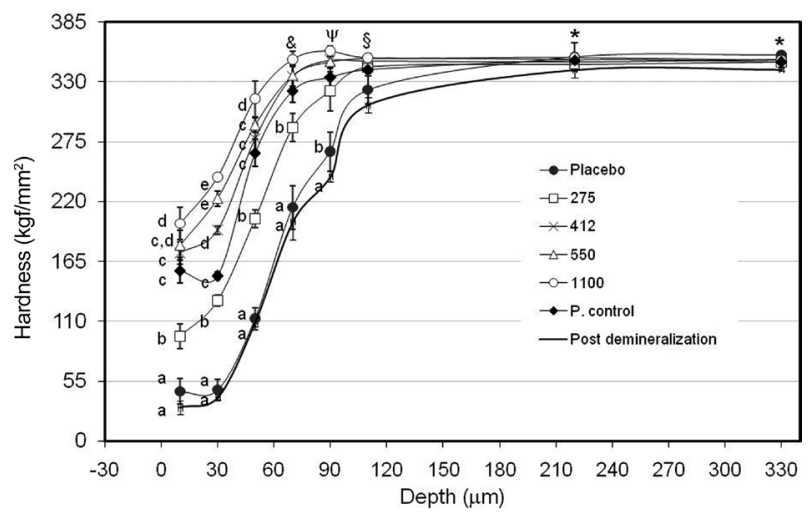

Figure 2. Cross-sectional hardness profiles (mean, $n=10$ ) at different depths in enamel blocks treated according to the experimental dentifrices and positive control. The bars denote standard deviations. Distinct letters represent statistically significant differences among groups in each depth (Student-Newman-Keuls; $p<0.05$ ). (\&) not statistically different among groups 412, 550, 1100 and P. control. $(\psi)$ not statistically different among groups $275,412,550,1100$ and P. control. (§) not statistically different among groups Placebo, 275, 412, 550, 1100 and P. control.

Table 1. Mean values (standard deviation) of hardness analysis $(n=10)$ according to the different treatments

\begin{tabular}{lccccc}
\hline Dentifrice & $\mathrm{SH}$ & $\mathrm{SH}_{1}$ & $\mathrm{SH}_{2}$ & ${ }_{0} \mathrm{SH}_{\mathrm{R}}$ & $\Delta \mathrm{KHN}$ \\
\hline Placebo (no F) & $370.2^{\mathrm{a}}(12.6)$ & $53.0^{\mathrm{a}}(22.8)$ & $73.8^{\mathrm{a}}(37.4)$ & $6.8^{\mathrm{a}}(8.6)$ & $18,316.7^{\mathrm{a}}(2,654.7)$ \\
$275 \mu \mathrm{gF} / \mathrm{g}$ (experimental) & $368.7^{\mathrm{a}}(17.5)$ & $56.7^{\mathrm{a}}(28.8)$ & $146.5^{\mathrm{b}}(35.3)$ & $29.5^{\mathrm{b}}(7.2)$ & $11,100.5^{\mathrm{b}}(2,228.0)$ \\
$412 \mu \mathrm{gF} / \mathrm{g}$ (experimental) & $372.0^{\mathrm{a}}(15.2)$ & $55.0^{\mathrm{a}}(24.6)$ & $164.5^{\mathrm{b}, \mathrm{c}}(32.3)$ & $34.8^{\mathrm{b}, \mathrm{c}}(5.8)$ & $6,152.3^{\mathrm{c}, \mathrm{e}}(1,339.0)$ \\
$550 \mu \mathrm{gF} / \mathrm{g}$ (experimental) & $371.9^{\mathrm{a}}(12.5)$ & $55.5^{\mathrm{a}}(20.3)$ & $188.7^{\mathrm{b}, \mathrm{c}}(43.1)$ & $42.6^{\mathrm{c}}(11.2)$ & $4,889.2^{\mathrm{c}, \mathrm{d}}(1,024.9)$ \\
$1,100 \mu \mathrm{gF} / \mathrm{g}$ (experimental) & $365.2^{\mathrm{a}}(17.1)$ & $48.8^{\mathrm{a}}(27.1)$ & $205.8^{\mathrm{c}}(46.0)$ & $50.4^{\mathrm{c}}(12.7)$ & $4,247.5^{\mathrm{c}}(1,519.1)$ \\
Crest $^{\mathrm{TM}}(1,100 \mu \mathrm{gF} / \mathrm{g})$ & $366.2^{\mathrm{a}}(16.5)$ & $51.1^{\mathrm{a}}(23.8)$ & $180.2^{\mathrm{b}, \mathrm{c}}(37.8)$ & $41.5^{\mathrm{c}}(8.9)$ & $7,408.0^{\mathrm{e}}(857.3)$ \\
\hline
\end{tabular}

Means followed by distinct letters are significantly different (Tukey's test: $\mathrm{SH}, \mathrm{SH}_{1}, \mathrm{SH}_{2}$ and $\% \mathrm{SH}_{\mathrm{R}}$. Dunn's test: $\Delta \mathrm{KHN}$. p<0.05). $\mathrm{SH}$ : surface hardness (baseline); $\mathrm{SH}_{1}$ : post-demineralization surface hardness; $\mathrm{SH}_{2}$ : surface hardness after $\mathrm{pH}$ cycling. 
Positive control showed a lower remineralization rate of subsurface lesion (at $30 \mu \mathrm{m}$ ) when compared with acidic dentifrice with 412,550 and 1,100 $\mu \mathrm{gF} / \mathrm{g}$. All experimental dentifrices with fluoride promoted remineralization of subsurface lesion.

\section{Discussion}

Many efforts have been made to reduce fluoride concentration in dentifrices without losing their anticariogenic efficacy, such as the use of trimetaphosphate (13). Acidic low fluoride dentifrices are able to keep the same fluoride concentration in dental plaque and to reduce fluoride ingestion in comparison to the conventional dentifrice (14). However, so far, there are no data regarding the ability of these dentifrices on improving enamel remineralization.

The possibility that acidic dentifrices might produce demineralization on enamel surface previously demineralized instead of enamel remineralization was discarded based on the increased values of $\mathrm{SH}_{2}$ and $\% \mathrm{SH}_{\mathrm{R}}$ after $\mathrm{pH}$ cycling and treatment with low fluoride acidic dentifrices, even in placebo group. Moreover, the reduction of the dentifrices does not increase their abrasiveness (8). There was an

showed that the used $\mathrm{pH}$ cycling model is suitable to evaluate the remineralization capacity of acidic dentifrices with different $\mathrm{F}$ concentrations.

The current study used dentifrices with $\mathrm{pH} 4.5$ and showed good results even in low $\mathrm{F}$ concentration. Dentifrices with 412 and $550 \mu \mathrm{gF} / \mathrm{g}$ showed similar or better results in comparison to that of positive control. These data suggest that $\mathrm{pH}$ reduction increased the reactivity between fluoride in dentifrices and enamel, in a mode of action similar to acidic fluoride gels: the acidified $\mathrm{pH}$ dissolves the superficial layers of enamel and the released calcium is precipitated as calcium fluoride (15). Calcium fluoride adsorbs to enamel surface acting as a fluoride reservoir, which, in turn, is released when the $\mathrm{pH}$ of the environment drops $(16,17)$. The $\mathrm{pH}$ reduction of oral environment during the dentifrice treatment does not seem to affect fluoride bioavailability (18).

Comparing positive control and 1,100 $\mu \mathrm{gF} / \mathrm{g}$ acidic dentifrice, there were no significantly differences in $\% \mathrm{SH}_{R}$ values. On the other hand, $\triangle K H N$ was lower in group treated with 1,100 $\mu \mathrm{gF} / \mathrm{g}$ acidic dentifrice. These results may be explained by the cross-sectional profiles, which showed a higher remineralization on the subsurface area of enamel (20-70 $\mu \mathrm{m})$ of the 1,100 $\mu \mathrm{g} \mathrm{F/g}$ dentifrice when compared with the positive control. The $\mathrm{pH}$ reduction increases $\mathrm{CaF}_{2}$ deposition on enamel $(5,19)$, promoting phosphorus incorporation in the enamel structure (20). During $\mathrm{pH}$ cycling, a higher $\mathrm{CaF}_{2}$ formation increases the formation of fluoride reservoirs on enamel surface, which increases $\% \mathrm{SH}_{\mathrm{R}}$ and mineral gain by subsurface lesion. Moreover, $\mathrm{CaF}_{2}$ formation depends on calcium and phosphate availability in environment (21). In the present study, phosphoric acid is added to dentifrices to reduce the decrease of $\mathrm{pH}$. In the present study, phosphoric acid was used in the acidified toothpastes, which led to different phosphorus concentrations in the dentifrices. However, it is unlikely that phosphorus itself is responsible for the better anticariogenic action of the acidified toothpastes because only a mild correlation was found between $\% \mathrm{SH}_{R}$ $(r=0.56)$ or $\triangle K H N(r=-0.35)$ and $P$ concentration $(p>0.05)$. Moreover, Brighenti et al. (7) found that the positive control toothpaste contained 10-fold more phosphorus than the acidified toothpastes, but the 550 and 1,100 $\mu \mathrm{g} \mathrm{F/g} \mathrm{experimental} \mathrm{pastes} \mathrm{showed} \mathrm{similar} \mathrm{results.} \mathrm{In} \mathrm{the}$ present study, the $1,100 \mu \mathrm{gF} / \mathrm{g}$ acidic dentifrice presented 3 times more phosphorus concentration than 412 and 550 $\mu \mathrm{gF} / \mathrm{g}$ acidic dentifrice; however they showed the same remineralization rate.

The increase in the amount of phosphorus concentration with the increase of fluoride concentration in dentifrices is directly related to the fact that the addition of $\mathrm{NaF}$ increases the product's $\mathrm{pH}$ to around 8.0. Thus, a higher amount of phosphoric acid is needed to set the $\mathrm{pH}$ to 4.5 in dentifrices with 1,100 ppm $F_{1}$ as also observed by Brighenti et al. (6). However, the low fluoride dentifrices (412 and $550 \mathrm{ppm}$ F) showed similar results when compared with the 1,100 acidulated dentifrice, which corroborates to the hypothesis that low $\mathrm{pH}$ - and not the amount of phosphorus - is responsible for the better performance of acidic toothpastes, as stated earlier (6).

Previous studies have shown that enamel microhardness values do not have a linear correlation with mineral content $(22,23)$. Thus, in the present study, the authors did not convert the hardness values into mineral content. Instead, the integrated loss of subsurface hardness $(\triangle K H N)$ was calculated. Despite this limitation, hardness evaluation has the advantage of providing additional information, such as mechanical properties and structural integrity, which cannot be obtained by mineral content assessment (22).

Literature does not show advantages of using acidic dentifrices compared with neutral dentifrices. However, the results found in the present study demonstrated that low $\mathrm{pH}$ improves remineralization capacity of dentifrices with reduced fluoride concentration. The European Academy of Pediatric Dentistry recommends that dentifrices with low fluoride concentration should be used twice a day by children aged 2 to 6 years (24). The manufacture of low 
fluoride acidic dentifrice can be stimulated by several studies in the literature that demonstrate favorable results when compared with a standard dentifrice $(6,7,25)$. In a clinical trial, the low fluoride acidic dentifrice demonstrated similar effectiveness to that of a standard neutral dentifrice in high-caries-risk children living in a fluoridated area (25).

The results of this study are useful to support further clinical and/or in situ studies. They encourage the benefits of reducing fluoride content in dentifrices combined to $\mathrm{pH}$ reduction with no further prejudice of remineralization properties, especially to children at high risk for the development of dental fluorosis. Based on the outcomes, it may be concluded that acidic dentifrice $(\mathrm{pH} \mathrm{4.5)}$ with $550 \mu \mathrm{gF} / \mathrm{g}$ showed similar capacity to promote enamel remineralization as that of a standard dentifrice.

\section{Resumo}

0 presente estudo objetivou avaliar a capacidade de dentifricios fluoretados acidulados $(\mathrm{pH} 4,5)$ em promover a remineralização do esmalte utilizando um modelo de ciclagem de $\mathrm{pH}$ e compará-lo a um dentifrício padrão $(1.100 \mu \mathrm{gF} / \mathrm{g})$. Blocos de esmalte tiveram suas superfícies polidas e a dureza de superficie determinada (SH). Em seguida, foram submetidos à desmineralização subsuperficial e a dureza de superficie pós-desmineralização foi determinada. Os blocos foram divididos em seis grupos experimentais ( $n=10)$ : placebo (controle negativo), 275, 412, $550,1.100 \mu \mathrm{gF} / \mathrm{g}$ e um dentifricio padrão (controle positivo). Os blocos foram submetidos à ciclagem de $\mathrm{pH}$ durante seis dias e tratamentos com dentifricio diluído duas vezes por dia. Após a ciclagem de $\mathrm{pH}$, a dureza de superfície e em secção transversal foram avaliadas para obtenção da porcentagem de recuperação de dureza de superfície $\left(\% \mathrm{SH}_{\mathrm{R}}\right)$ e área integrada da perda de dureza de subsuperfície $(\Delta K H N)$. Os resultados mostraram que $\% \mathrm{SH}_{\mathrm{R}}$ foi semelhante entre os dentifrícios ácidos 412, 550, $1.100 \mu \mathrm{gF} / \mathrm{g}$ e controle positivo (teste de Tukey; $p>0,05$ ). Para $\triangle K H N$, o dentifrício acidulado com $550 \mu \mathrm{gF} / \mathrm{g}$ mostrou uma performance melhor quando comparado ao controle positivo. Conclui-se que os dentifricios acidulados $550 \mu \mathrm{gF} / \mathrm{g}$ apresentaram capacidade de remineralização semelhante ao controle positivo.

\section{Acknowledgments}

The authors thank CNPq/PIBIC (National Counsel for Technological and Scientific Development) for the scholarship and FGM Produtos Odontológicos Ltda. for manufacturing the experimental dentifrices.

\section{References}

1. Wong MC, Glenny AM, Tsang BW, Lo EC, Worthington HV, Marinho VC. Topical fluoride as a cause of dental fluorosis in children. Cochrane Database Syst Rev 2010;(1):CD007693.

2. Pessan JP, Silva SMB, Buzalaf MAR. Evaluation of the total fluoride intake of 4-7-year-old children from diet and dentifrice. J Appl Oral Sci 2003;11:150-156

3. Hamilton J. New CDC report offers fluoride use tips. J Calif Dent Assoc 2001;29:723-724.

4. Peters MC. Strategies for noninvasive demineralized tissue repair. Dent Clin N Am 2010;54:507-525.
5. Saxegaard E, Rölla G. Fluoride acquisition on and in human enamel during topical application in vitro. Scand J Dent Res 1988;96:523-535.

6. Brighenti FL, Delbem ACB, Buzalaf MAR, Ribeiro DB, Sassaki KT. In vitro evaluation of acidified toothpastes with low fluoride content. Caries Res 2006;40:239-244.

7. Alves KMRP, Pessan JP, Brighenti FL, Franco KS, Oliveira FAL, Buzalaf $M A R$, et al.. In vitro evaluation of the effectiveness of acidic fluoride dentifrices. Caries Res 2007;41:263-267.

8. Alves KM, Pessan JP, Buzalaf MA, Delbem ACB. In vitro evaluation of the abrasiveness of acidic dentifrices. Eur Arch Paediatr Dent 2009;10:4345.

9. Vieira AEM, Delbem ACB, Sassaki KTS, Rodrigues E, Cury JA, Cunha RF. Fluoride dose-response in $\mathrm{pH}$-cycling models using bovine enamel. Caries Res 2005;39:514-520.

10. Fiske $\mathrm{CH}$, Subbarow $\mathrm{Y}$. The colorimetric determination of phosphorus. J Biol Chem 1925;66:375-400.

11. Queiroz CS, Hara AT, Leme FP, Cury JA. pH-cycling models to evaluate the effect of low fluoride dentifrice on enamel de- and remineralization. Braz Dent J 2008;19:21-27.

12. Argenta RM, Tabchoury CP, Cury JA. A modified pH-cycling model to evaluate fluoride effect on enamel demineralization. Braz Oral Res 2003;17:241-246.

13. Takeshita EM, Castro LP, Sassaki KT, Delbem, ACB. In vitro evaluation of dentifrice with low fluoride content supplemented with trimetaphosphate. Caries Res 2009;43:50-56

14. Buzalaf MA, Vilhena FV, lano FG, Grizzo L, Pessan JP, Sampaio FC, et al.. The effect of different fluoride concentrations and $\mathrm{pH}$ of dentifrices on plaque and nail fluoride levels in young children. Caries Res 2009;43:142-146.

15. Moreno EC. Role of Ca-P-F in caries prevention: chemical aspects. Int Dent J 1993;43:71-80.

16. Featherstone JDB, O'Reilly MM, Shariati M, Brugler S. Enhancement of remineralization in vitro and in vivo. In: Factors relating to demineralization and remineralization of the teeth. Leach (Editor). Oxford: IRL Press 1986; p23-24.

17. ten Cate JM. In vitro studies on the effects of fluoride on de- and remineralization. J Dent Res 1990;69:614-619.

18. Olympio KP, Bardal PA, Cardoso VE, Oliveira RC, Bastos JR, Buzalaf MAR. Low-fluoride dentifrices with reduced $\mathrm{pH}$ : fluoride concentration in whole saliva and bioavailability. Caries Res 2007;41:365-370.

19. Ogaard B. $\mathrm{CaF}_{2}$ formation: cariostatic properties and factors of enhancing the effect. Caries Res 2001;35:40-44.

20. Christoffersen J, Christoffersen MR, Kibalczyc W, Perdok WG. Kinetics of dissolution and growth of calcium fluoride and effects of phosphate. Acta Odontol Scand 1988;46:325-336.

21. Kardos S, Shi B, Sipos T. The in vitro demineralization potential of a sodium fluoride, calcium and phosphate ion-containing dentifrice under various experimental conditions. J Clin Dent 1999;10:22-25.

22. Buchalla W, Imfeld T, Attin T, Swain MV, Schmidlin PR. Relationship between nanohardness and mineral content of artificial carious enamel lesions. Caries Res 2008;42:157-163.

23. Delbem AC, Sassaki KT, Vieira $A E$, Rodrigues $E_{1}$ Bergamaschi $M$, Stock SR, et al.. Comparison of methods for evaluating mineral loss: hardness versus synchrotron microcomputed tomography. Caries Res 2009;43:359-365.

24. Oulis C, Raadal M, Martens L. Guidelines on the use of fluoride in children: an EAPD policy document. Eur J Paediatr Dent 2000;1:7-12.

25. Vilhena FV, Olympio KPK, Lauris JRP, Delbem ACB, Buzalaf MAR. Lowfluoride acidic dentifrice: a randomized clinical trial in a fluoridated area. Caries Res 2010;44:478-484.

Received April 13, 2012 Accepted January 22, 2013 